\title{
AN ECONOMIC AND LEGAL ANALYSIS OF UNION REPRESENTATION ON GORPORATE BOARDS OF DIRECTORS
}

On May 13, 1980, Douglas Fraser, President of the United Automobile Workers [UAW], was elected to the board of directors of the Chrysler Corporation. ${ }^{1}$ Fraser's election was the product of a four-year UAW campaign for representation on the board of a major auto manufacturer. ${ }^{2}$ The UAW's demand was a rare expression of such an interest on the part of a United States union, ${ }^{3}$ but one that is likely to occur more frequently in the future. ${ }^{4}$

Fraser and future union representatives on corporate boards face a serious conflict of interest under current corporate and labor law. A corporate director has a fiduciary duty to the corporation's shareholders. ${ }^{5}$ A union official, however, has a fiduciary duty to the union and its members. A union official on a corporate board thus has a duty to both union members and to shareholders. ${ }^{6}$ Whenever these two groups' interests conflicted, therefore, the union officer would have to breach one of these duties.

The topic of this Comment is the manner in which the law should deal with this conflict. Part. I. briefly examines the nature of the fiduciary duties of union officers and corporate directors, concluding that the conflict between these duties is irremediable under existing law. Part II argues that relaxation of the usual director's duty to shareholders in order to allow union representation of workers' interests ${ }^{7}$ could be expected to have a generally favorable impact on economic efficiency. Part III examines some important noneconomic policies that would be furthered by allowing union representation. Part IV presents a general standard for

1 New York Times, May 14, 1980, at D1, col. 3.

2 See New York Times, Oct. 24, 1979, at DI, col. 4. Cf. Murphy, Workers on the Board: Borrowing a European Idea, 27 LAB. L.J. 751, 751 (1976) (referring to the U.A.W.'s first announcement in 1976).

3 The U.A.W.'s 1976 demand for board representation was "without precedent in American labor relations. ..." Murphy, supra note 2, at 751. See New York Times, supra note 2. But see Blumberg, Reflections on Proposals for Corporate Reform Through Change in the Composition of the Board of Directors: "Special Interest" or "Public" Directors, 53 B.U.L. Rev. 547, 566 (1973).

4 See Murphy, supra note 2, at 762; Blumberg, supra note 3, at 572-73; Raskin, The Labor Leader As Company Director, N.Y. Times, Apr. 27, 1980, at Cl, col. 1.

5 See infra text accompanying notes 9-12.

6 See infra text accompanying notes 15-17.

7 The reason for this Comment's emphasis on union, rather than worker, representation is explained below. See infra note 68 . 
the fiduciary duty of a union representative on a corporate board with respect to both the workers and the shareholders, and uses this standard to define the union representative's responsibilities in several important factual contexts. ${ }^{8}$

\section{The Fiduciary Responsibilities of Corporate Directors aND UNION OfFICIALS}

The directors of a publicly-held corporation are fiduciaries to the corporation's shareholders. ${ }^{9}$ The particular requirements of this duty have been stated variously by different statutes ${ }^{10}$ and courts. ${ }^{11}$ One well-known description of the duty requires, inter

8 This Comment considers only the context of a large, publicly-held corporation and a strong union, such as the Chrysler and UAW situation, because this is the environment most likely to spawn such representation. It is assumed that the union and the corporation have agreed voluntarily to such representation. See infra text accompanying notes 21-33. This Comment does not address the broader issue whether a statutory requirement of worker representation, which some Western European countries have, see infra note 92, would be desirable for the United States. Moreover, this Comment's analysis applies solely to minority union board representation, because majority union representation might raise issues of separation of ownership and control. See generally F. KNIGHT, Rusk, UNCERTAINTY AND Profit 264-79 (1971); Dreze, Some Theory of Labor Management and Participation, 44 EconoMETRICA 1125, 1134-35 (1976).

9 This duty has been described as owed to the corporation, to the shareholders, and to both. Compare Litwin v. Allen, 25 N.Y.S.2d 667 (Sup. Ct. 1940) ("It is clear that a director owes loyalty and allegiance to the company-a loyalty that is undivided and an allegiance that is influenced ... by no consideration other than the welfare of the corporation."), with Dodge v. Ford Motor Co., 204 Mich. 459, 507,170 N.W. 668, 684 (1919) ("A business corporation is organized and carried on primarily for the profit of the shareholders. The powers of the directors are to be employed for that end."). This is unimportant, however, because under any of these formulations, the duty is not owed to the employees. See, e.g., Pepper v. Litton, 308 U.S. 295, 307 (1939) (referring to "the entire community of interests in the corporation-creditors as well as shareholders") (footnote omitted). Although in Shlensky $v$. Wrigley, the court indicated that corporate directors properly could consider the effects of their decisions on the surrounding neighborhood, 95 Ill. App. $2 d$ 173, 180-81, 237 N.E.2d 776, 780 (1968), the court's discussion makes it clear that such factors may be given weight only to the extent that they affect the long-run interests of the corporation. Id. The director's duty of care, therefore, will be referred to throughout this Comment as directed to the shareholders.

10 Compare MOder Business Corporation Act $\$ 35$ (1979) ("A director shall perform his duties as a director ... in good faith, in a manner he reasonably believes to be in the best interests of the corporation, and with such care as an ordinarily prudent person in a like position would use under similar circumstances.") with N.C. GEN. Stat. $\$ 55-35$ (1975) ("Officers and directors shall be deemed to stand in a fiduciary relation to the corporation and to its shareholders and shall discharge [their] duties . . . in good faith, and with that diligence and care which ordinarily prudent men would exercise under similar circumstances in like positions.").

11 Compare infra text accompanying note 12 with Kavanaugh v. Kavanaugh Knitting Co., 226 N.Y. 185, 193, 123 N.E. 148, 151 (1919) ("The directors are bound by all those rules of conscientious fairness, morality, and honesty in purpose which the law imposes [on] those ... under . . . fiduciary obligations and responsibilities. They are held, in official action, to the extreme measure of candor, unselfishness, and good faith."). 
alia, a director's "loyalty and allegiance to the company .... . He may not profit at the expense of his corporation and in conflict with its rights .... He is required to use his independent judgment. In the discharge of his duties a director must . . . act honestly and in good faith, but that is not enough. He must also exercise some degree of skill and prudence and diligence." 12

A central premise established by the case law on directorial duties is the prohibition against director advancement of private interests at the expense of the shareholders. ${ }^{13}$ Thus, a union board representative would not be able to vote to further employee interests, when they conflicted with shareholder interests, without breaching the director's fiduciary duty to the shareholders. ${ }^{14}$ Voting to further shareholder interests when they conflicted with worker interests, however, could violate another duty to which union officers are held by law. Section 501 of the Landrum-Griffin Act imposes a fiduciary responsibility on union officials "to refrain from dealing with [the union] as an adverse party or in behalf of an adverse party in any matter connected with his duties . . . "15

12 Litwin v. Allen, 25 N.Y.S.2d at $677-78$. In practical terms a corporate director has several responsibilities. For example, directors are to exercise "in good faith, the infinite details of business, including the wages which shall be paid to employees, the number of hours they shall work, the conditions under which labor shall be carried on, and the prices for which products shall be offered to the public." Dodge v. Ford Motor Co., 204 Mich. at 507, 170 N.W. at 684.

13 See, e.g., Zahn v. Transamerica Corp., 162 F.2d 36, 43 (3d Cir. 1947) ("I $t]$ he directors owe a duty of managing the corporate affairs honestly and impartially in behalf of the corporation and all the stockholders ... ".) (quoting 19 C.J.S. Corporations $\$ 764)$; H. Vincent Allen \& Assocs. v. Weis, 63 Ill. App. 3d 285, 290-91, 379 N.E.2d 765, 769 (1978) ("an important consideration in the determination of breach of fiduciary duty [is] whether the directors and officers were 'actively exploiting' their positions within the corporation for their own personal benefit"); Miller v. Miller, 301 Minn. 207, 219, 222 N.W.2d 71, 78 (1974) ("[w]e acknowledge the well-recognized, common-law principle that [a director] may not exploit his position as an 'insider' by appropriating to himself a business opportunity properly belonging to the corporation."); Adelman v. Conotti Corp., 215 Va. 782, 790,213 S.E.2d 774, 779 (1975) (quoting Rowland v. Kable, 174 Va. 343, 6 S.E.2d $633(1940)$ ) ("[t]he unbending rule is that the director must ... [not place] himself in a position where his individual interest clashes with his duty to his corporation."). The remedy for a breach of the director's duty can be a severe one. See, e.g., N.Y. Trust Co. v. Amer. Realty Co., 244 N.Y. 209, 216, 155 N.E. 102, 104 (1926) ("it has frequently been held that a director or officer of a corporation must account to the corporation for profits received in disregard of duty owed to the corporation.").

14 But see Comment, Serving T'wo Masters: Union Representation on Corporate Boards of Directors, 81 Conum. L. Rey. 639, 652-60 (1981), in which the author asserts that this may not violate the director's fiduciary duty to shareholders. Because the possibility of a court finding that there is a violation remains, however, this Comment advocates an explicit change in the law. See infra note 17.

${ }^{15}$ Labor-Management Reporting and Disclosure (Landrum-Griffin) Act $\$ 501$ (a), 29 U.S.C. $\$ 501$ (a) (1976). The pertinent text of this provision is as follows:

The officers, agents, shop stewards, and other representatives of a labor organization occupy positions of trust in relation to such organization and 
Advancing the shareholders' interests, when worker or union interests were implicated, ${ }^{16}$ arguably would be dealing as an "adverse party," and therefore would be a violation of section $501 .{ }^{17}$

The issue, then, is what should be the legal standard of a union official's fiduciary duty as a corporate director. This Comment argues that the usual corporate director's duty to shareholders should be relaxed to allow a union representative to act to further worker interests. The economic and non-economic reasons for this conclusion are presented in the next two sections of this Comment.

its members as a group. It is, therefore, the duty of each such person, taking into account the special problems and functions of a labor organization ...., to refrain from dealing with such organization as an adverse party or in behalf of an adverse party in any matter connected with his duties and from holding or acquiring any pecuniary or personal interest which conflicts with the interests of such organization .....

16 Conflicts between these two duties-to the shareholders and to the workerscould arise anytime possible board decisions would have the effect of imposing costs on the workers as a group, such as board decisions concerning plant closings and layoffs. Cf. New York Times, Nov. 26, 1979, at D9, col. 1 (U.A.W. president Fraser's remarks about a Chrysler plant-closing). Less dramatically, board decisions that directly or indirectly affect working conditions also may impose costs on the workers, and thus give rise to a conflict of duties.

17 But see Comment, supra note 14, which argues that a union official on a corporate board in most circumstances would not violate section 501 of the LandrumGriffin Act. That Comment argues, moreover, that a union director would not violate either section 8(a) (2) of the National Labor Relations Act, making it unlawful for management to "dominate or interfere with the . . administration of any labor organization," National Labor Relations Act $\$ 8(\mathrm{a})(2)$, as amended, 29 U.S.C. $\$ 158(\mathrm{a})(2)$ (1976), or the union official's duty of fair representation, which prohibits arbitrary or discriminatory treatment of employees or groups of employees, see Vaca v. Sipes, 386 U.S. 171, 191 (1967); Steele v. Louisville \& N.R.R., 323 U.S. 192, 201-04 (1944). That Comment also contends that a union representative on a corporate board generally could represent employee interests without violating the fiduciary duty to the shareholders. Comment, supra note 14, at 652-60.

That Comment admits, however, that there could be labor law violations found under at least some courts' analyses. Id. 642. In addition, the Comment notes that section 50I "fails to define the precise scope of [a union] official's fiduciary obligation," id. 645, and that a director owing a duty to groups other than shareholders, such as "employees, consumers, and the general public, does not yield a precise standard for evaluating the conduct of corporate directors," id. 655. Moreover, the Comment's general conclusions concerning the corporate director's fiduciary duty explicitly only apply to actions designed to advance at least the long-run interests of the shareholders, because few courts have been willing to discard totally the traditional model of a duty owed solely to the shareholders. See id.

This Comment does not question these general conclusions. Rather than possibly opening the union board representative to liability under differing interpretations of the admittedly ambiguous legal standards embodied in various corporate and labor law provisions, however, this Comment advocates an explicit acceptance and legislative (or, failing that, judicial) revision of the provisions defining corporate directors' duties to provide for differing fiduciary obligations of such union officials. Furthermore, this Comment recognizes that the shape of this fiduciary duty for a union official on a corporate board is ultimately a question of legal policy, and therefore presents economic and noneconomic policy grounds supporting the legal changes advocated. 


\section{Economic Policy and Union Representation}

The potential economic impact of union representation of employee rather than shareholder interests on a corporate board supports modification of the director's usual fiduciary duty to shareholders. Although somewhat theoretical in nature, the economic analysis that follows suggests that union board membership on the workers' behalf would increase both allocative efficiency-the optimal deployment of society's resources-and efficiency in the management of the specific corporation.

The economic approach of this Comment is primarily "institutional" in character, ${ }^{18}$ focusing on transactional and organizational costs: "the comparative costs of planning, adapting, and monitoring task completion under alternative governance structures." 19 Thus, this approach entails analysis of the relative costs and efficiencies resulting from alternative ways of organizing and managing a corporation. ${ }^{20}$ The two such ways relevant to this

18 One author described an institutional approach as the following:

A broadly based interest among economists in what might be referred to as the "new institutional economics" has developed in recent years. Aspects of mainline microtheory, economic history, the economics of property rights, comparative systems, labor economics, and industrial organization have each had a bearing on this renaissance. The common threads that tie these various studies together are: (1) an evolving consensus that received microtheory, as useful and powerful as it is for many purposes, operates at too high a level of abstraction to permit many important microeconomic phenomena to be addressed in an uncontrived way; and (2) a sense that the study of "transactions," which concerned the institutionalists in the profession some forty years ago, is really a core matter and deserves renewed attention. Unlike the earlier institutionalists, however, the current group is inclined to be eclectic. The new institutional economists both draw on microtheory and, for the most part, regard what they are doing as complementary to, rather than a substitute for, conventional analysis.

O. Williamson, Markets and Hrerarches: Analysis and ANTitrust Implications 1 (1975); cf. J. ADDison \& W. Stebert, The Market For Labor: AN ANarytical Treatment 5 (1979) ("Institutionalists . . . reject abstract general theories and advocate an inductive and interdisciplinary approach. ...").

$19 \mathrm{O}$. Williamson, The Economics of Organization: The Transaction Cost Approach 7 (Feb. 1981) (Center for the Study of Org'l Innov., Univ. of Pennsylvania, Disc. Paper No. 96).

20 See generally Williamson, The Economics of Antitrust: Transaction Cost Considerations, 122 U. PA. L. REv. 1439, 1442-47 (1974).

There is a body of formal, mathematical economic literature on worker participation. See, e.g., J. Vanek, The General Theony of Labor-Managed Econommes (1970); Atkinson, Worker Management and the Modern Industrial Enterprise, 87 Q.J. ECoN. 375 (1973); Domar, The Soviet Collective Farm as a Producer Cooperative, 56 AM. Ecov. Rev. 734 (1966); Furubotn, The Long-Run Analysis of the Labor-Managed Firm: An Alternative Interpretation, 66 AM. Econ. Rev. 104 (1976); Meade, The Theory of Labour-Managed Firms and of Profit Sharing, 82 Econ. J. 402 (1972); Steinherr, On the Efficiency of Profit Sharing and Labor Participation in Management, 8. BeLL J. Econ. 545 (1977); Ward, The Firm in Illyria: Market Syndicalism, 48 AM. Econ. REv. 566 (1958). For a rigorous, but nonmathematical, 
discussion are the traditional corporate board and a corporate governance structure that includes union representation of workers on the board of directors.

Four types of costs and efficiencies are analyzed in the following subsections. The first subsection examines the agreement to provide the union with board representation in light of the economic theory of free exchange. The second subsection assesses the distribution of the risk of partial or complete corporate failure between shareholders and workers, along with the relative ability of each group to shift this risk. The third subsection analyzes the implications of union representation for the efficient governance of the contractual relationship between the union and the corporation, particularly in light of two kinds of uncertainty inherent in that relationship. Finally, the fourth subsection examines the effects that union board representation might have on the ability of the board to ensure that the corporate management is operating efficiently.

\section{A. The Economics of Free Exchange}

The union's and the corporation's agreement to have union board representation is prima facie an economically beneficial exchange between the two parties. ${ }^{21}$ This presumption of economic benefit stems from the basic proposition of economic theory that, given certain assumptions, ${ }^{22}$ "[v]oluntary trade is mutually ben-

treatment of worker management, see Vanek, Decentralization Under WorkersManagement: A Theoretical Appraisal, 59 AM. Econ. Rev. 1006 (1969).

This literature is not examined in this Comment for two reasons. First, the formal models in this literature are, for the most part, concerned with the workermanaged enterprise, not with union (or worker) representation. For an exception, see Steinherr, supra, this note. Steinherr concludes that, "whatever the objective function of the firm, it requires fairly mild assumptions to make some profit sharing and participation in decision making always optimal." Id. 552.

Second, and more important, formal neoclassical economic models, which assume that the firm is producing efficiently, are poorly suited to examination of the relative efficiency of alternative means of organizing transactions within the firm. See O. Williamson, The Evolution of Hierarchy 1-2 (Fels Discussion Paper No. 91, July, 1976) (located in the University of Pennsylvania School of Public and Urban Policy library). French economist Jacques Dreze points to "the merits and limitations of static equilibrium analysis, which provides very clear answers to over-simplified questions. ..." Dreze, supra note 8, at 1128.

21 Note that the union receives from the exchange a board position presumably to represent the workers. This Comment argues that because of economic and noneconomic rationales the union should be able to represent the worker on the board without legal conflict of interest problems. Unless the parties explicitly indicate to the contrary, therefore, it is presumed that management and the board or shareholders understood that the union would represent worker interests. UAW president Fraser made it very clear prior to his election to the Chrysler board that he would represent worker interests. See T. C. Hayes, Fraser Board Role Riles Critics, Raises Questions, N.Y. Times, Nov. 26, 1979, at D1, col. 1.

22 The most important of these assumptions is that individuals act rationally to maximize their individual welfare. See generally J. HENDERSON \& R. QUANDT, 
eficial." 23 Given some additional assumptions, ${ }^{24}$ economic theory asserts that voluntary exchange will result in the shift of resources

Mrcroeconomic Theory 6 ( $2 \mathrm{~d}$ ed. 1971); J. Hurshremifer, Price Theory and Applications 88-89 (2d ed. 1980); W. Nicholson, INTERMEDiate MrcroecoNOMICS AND ITS Application 9, 52 ( $2 \mathrm{~d}$ ed. 1979); G. Stiglen, The Theory of PrICE 55-60 (3d ed. 1966). For an effective defense of this fundamental postulate of economics, see R. POSNER, Economrc ANALYSTS OF LAW 12-14 (2d ed. 1977).

Also very important is the assumption that individuals fully understand the relevant characteristics of the goods available and know their relative prices, and in particular that such information is not available to only one party. See Arrow, The Organization of Economic Activity: Issues Pertinent to the Choice of Market Versus Non-market Allocation, in I Subcommitrese on Economy IN Government, Jonnt Economic Commitree, 91st Cong., Ist Sess., The Analysis and EvalvaTion of Public Expenditures: The PPB System 47, 54-56 (Comm. Print 1969); Akerlof, The Market for "Lemons": Quality Uncertainty and the Market Mechanism, 84 Q.J. EcoN. 488 (1970).

This assumption about perfect information, though never met in an absolute sense, is less significant in the strong union/large corporation context assumed throughout this Comment than elsewhere. See supra note 8. Both union and management negotiators may be assumed to have substantially correct information about the relative values to each of them of the different subjects of the negotiation, including union representation on the corporate board, at least by the time they settle. The ongoing nature of the collective bargaining relationship makes this particularly true because each side can draw on prior events as a source of such information. In addition, an employer is obligated to provide certain types of information needed by the union to carry out its duties of negotiating and policing the collective agreement. See, e.g., NLRB v. Acme Indus. Co., 385 U.S. 432 (1967); Timken Roller Bearing Co. v. NLRB, 325 F.2d 746 (6th Cir. 1963), cert. denied, 376 U.S. 971 (1964).

The only potential information problem occurs with respect to the shareholders, who may not be able to assess a management proposal for union representation. See infra text accompanying notes 81-82. This possible inability is a troubling problem, but is not restricted to the issue of worker representation. Moreover, management ostensibly is seeking to further shareholder interests. See infra note 24. Union representation also may help alleviate this general problem by providing directors and shareholders with an alternative source of information to management. See infra text accompanying note 91.

$23 \mathrm{~J}$. Hurshrmenrer, supra note 22, at 190. See generally id. 164-75; W. NrchoLsoN, supra note 22 , at $9,44-51$.

24 The most important assumptions are that there be no significant costs (or benefits) not borne (received) by the party who caused them and that transaction costs be insignificant. See generally Arrow, supra note 22, at 55-60. Neither of these is liable to cause any problems in the strong union-large corporation setting assumed herein. To obtain the exchange agreement providing for union representation on the board, there may be several transaction costs. The principal costs would be negotiating, drafting, and administrating the agreement. The only effect such costs could have would be to prevent an otherwise efficient change from being negotiated; they could not facilitate negotiation of an inefficient change. Hence, they raise no issue with regard to the efficiency of a completed agreement for union representation.

External costs not borne by the causer raise no problems unless one posits that corporate directors or union leaders seek to advance interests other than those of the shareholders or workers respectively. This would suggest a general problem that would require broad institutional reform to correct, and would be only incidentally related to the specific issue of union representation. Indeed, union representation could help alleviate this problem. See infra notes 134-38 \& accompanying text. In addition, should these assumptions fail, later sections of this Comment establish that union representation on the board is nonetheless efficient. See infra sections IIC \& IID. 
"to those uses in which the value to consumers, as measured by their willingness to pay, is highest." ${ }^{25}$ Given such a shift of resources "pursuant to a voluntary transaction, we can be reasonably confident that the shift involves a net increase in efficiency." 26

The collective bargaining context, however, differs in important respects from the economic model of voluntary exchange. In particular, the collective bargaining relationship is not characterized solely by the voluntariness of the free exchange postulates, but rather involves some external compulsion: the parties must negotiate within a structure of legal requirements and limitations. ${ }^{27}$ But within this structure there remains room for the proposition to operate, in the limited sense that each party can be assumed to seek out the best possible bargain it can attain given the constraints on its behavior..$^{28}$ Thus, for example, a union that accepted an eight percent wage increase and a certain package of benefits and rules changes presumably thought it made the workers better off than any other choice to which the employer would have agreed. ${ }^{29}$ Similarly, management presumably thought that the agreement was the best it could have obtained for the corporation given the external constraints. ${ }^{30}$

$25 \mathrm{R}$. Posner, supra note 22, at 10 . Gains to the parties to the exchange do not in all cases enhance overall societal efficiency, which has been defined as "exploiting economic resources in such a way that 'value'-human satisfaction as measured by aggregate consumer willingness to pay for goods and services-is maximized." R. PoSNER, supra note 22 , at 10 (emphasis in original). An exchange may benefit the parties to it but also might impose costs on some third party such that total value is reduced. Such an exchange would be inefficient for society as a whole. Allocative efficiency is thus a measure of social, as opposed to individual, welfare.

26 R. POSNER, supra note 22, at 11.

27 See, e.g., National Labor Relations (Wagner) Act, ch. 372, \$\$1-13, 49 Stat. 449 (1935), as amended by the Labor Management Reporting and Disclosure (Landrum-Griffin) Act, Pub. L. No. 86-257, 73 Stat. 519 (1959) (codified at 29 U.S.C. $\$ \$ 151-197,401-531$ (1976)). There are also, of course, practical restraints. See, e.g., Summers, Judicial Review of Labor Arbitration or Alice Through the Looking Glass, 2 Buffalo L. REv. 1, 14-15 (1952); Cox, The Legal Nature of Collective Bargaining Agreements, 57 Mrch. L. REv. 1, 3 (1958).

28 In mathematical economic terms, the parties face constrained maximization problems, and will solve them to attain a local (as opposed to a global) maximum. Assuming that the external constraints were properly designed to increase social welfare, this local welfare maximization can be assumed to be efficient. Even if the external constraints are designed poorly, however, such local maximization would normally be efficiency-enhancing. See generally F. SCHERER, INDUSTrual MARKET Structure and Economic Performance 24-29 (2d ed. 1980).

29 It is assumed that there are no problems of inappropriate motivation of union officials such as desire to profit at the expense of employees. Cf. supra note 24.

30 Management purportedly tries to operate in the best interests of the corporation. Although this is a standard assumption in economic analysis, see J. HrrsHLEIFER, supra note 22 , at 265-66, it is not a necessary assumption because the board of directors or the stockholders must vote the union representative onto the 
Hence, when the Chrysler Corporation acceded to the UAW's demand for a position on the board of directors, it presumably considered this the best bargain it could reach for the corporation. ${ }^{31}$ In fact, the benefit that Chrysler received by electing Douglas Fraser to its board of directors was both obvious and substantial. In return for the board position, the UAW agreed to $\$ 203$ million worth of concessions for Chrysler from the collective bargaining agreement that it had negotiated with the three major domestic automakers-Ford, Chrysler, and General Motors. ${ }^{32}$ These enormous concessions were critical to Chrysler's continued operation. ${ }^{33}$ Thus, both parties benefited by the agreement.

In future cases, the quid pro quo for union board representation may be less evident. Nonetheless, the courts should presume, in the absence of strong evidence to the contrary, that both the union and the corporation benefit from such agreements.

\section{B. The Distribution of the Risk of Corporate Failure}

The traditional explanation for vesting corporate control in the shareholders is that shareholders, by providing the capital for the enterprise, bear the risk of failure. ${ }^{34}$ It thus seems equitable

board. Unless one posits that the directors are ineffective or seek to further their own interests rather than the corporation's, therefore, there is no problem. See supra note 24 and infra text accompanying notes $79-83 \& 91$.

31 This presumption would, of course, be rebuttable by shareholders in a suit against the board for breach of its fiduciary duties if the union representative had been elected by the board. But the burden on the stockholder-plaintiffs would require that they show both that better alternatives realistically were available and that the directors breached their fiduciary duties in approving union representation. The usual standards would apply for the issue whether the directors had breached their fiduciary duties. See generally W. Fuercher, Cyclopedia of the LaW of Pruvate Conporations, $\$ \$$ 989-1009 (rev. perm. ed. 1975).

32 New York Times, Oct. 26, 1979, at A1, col. 4. The U.A.W. had previously agreed to let Chrysler defer $\$ 200$ million in pension fund contributions for one year, id. D6, col. 3, and later agreed to an additional $\$ 243$ million in contract concessions, after Congress made government loan guarantees for Chrysler contingent upon such agreement, see New York Times, Jan. 6, 1980, § I, at 24, col. 3.

33 It could be argued that Chrysler acquiesced to the UAW's demands under duress, and that the courts should therefore refuse to recognize the agreement as being in Chrysler's best interests. But this argument is very weak in light of the contract concessions agreed to by the union, see supra note 32 and accompanying text, and the very limited voting power UAW president Fraser will have as one of 18 board members, see Fraser Board Role Riles Critics, Raises Questions, supra note 21, at D1, col. 1 .

34 See, e.g., F. KNICHT, supra note 8; at 270: "With human nature as we know it it would be impracticable or very unusual for one man to guarantee to another [a fixed wage] without being given power to direct his work." For a nice summary of this argument for control by those who provide capital, see Jonsson, Labour as RiskBeater, 2 CAMBRmge J. EcoN. 373, 373-74 (1978). For a very different explanation of control by capital, see C. LindBlom, Pormtics AND MARKETs 104-05 (1977) (suggesting that enterprises owned by workers who hire capital "do not exist simply because [of] . . the historically given distribution of wealth . . .."). 
to give the shareholders as much control as possible over their fates. Efficiency considerations also dictate placing ultimate control in the hands of those with the incentive to run the enterprise wellthose with something to lose. This reasoning for exclusive shareholder control is, however, flawed, because employees also bear some of the risk that a company will fail, ${ }^{35}$ and are less able to protect themselves from that risk than are shareholders.

The wages and other benefits that workers can extract from the corporation through collective bargaining are, of course, related to the general financial health of the corporation. The most direct and serious risk borne by the workers, however, is job loss. This risk represents two kinds of potential costs to the worker. The first is the transition costs of moving from one job to another. This includes income lost during the interim period, job search costs, and possible moving costs, as well as the emotional impact of unemployment. These costs will vary with local and general employment levels in the worker's field. In addition, transition costs may include losses from forced sale of assets such as a house, car, or used furniture, especially when job loss is sudden and unexpected.

The second type of cost borne by laid-off workers is lost economic rent: ${ }^{36}$ the wage loss the worker may take in a new job. In highly unionized industries, with which this Comment is primarily concerned, this loss can be considerable. For example, an auto worker who is forced to leave the industry and take an unskilled or semiskilled job in a nonunion industry probably will suffer a substantial loss in income.

Thus, the proposition that the suppliers of capital should control the enterprise because of the risk they bear ignores the reality that workers bear a substantial part of the risk of enterprise failure. This consideration is increasingly true in our interdependent modern society, as the option of total economic inde-

35 See generally Jonsson, supra note 34 .

The general argument here, in economic terms, can also be stated as an externality problem, see supra note 24 : the board is not taking into account the full economic cost of its decisions. Union representation might make the board more cognizant of the external costs imposed on workers, and thus lead to more socially optimal corporate decision-making.

36 Economic rent is

the difference between what the factors, or productive services, of a resource-owner earn in their current occupation and the minimum sum he is willing to accept to keep [them] there. It is then a measure of the resourceowner's gain from having the opportunity of placing his factors in the chosen occupation at the existing factor price, given the prices his factors would earn in all other occupations.

E.J. Mishan, Cost-Benefit Analysis 55 (1976). 
pendence is becoming less and less realistic. ${ }^{37}$

Workers not only bear a substantial portion of the risk of failure, they also are less able to protect themselves from this risk. Providers of capital can reduce the risk of losses from bad investments by diversifying their security holdings. ${ }^{38}$ Workers, on the other hand, can reduce risk only in much more limited ways. Workers cannot insure themselves against job loss, except to a limited extent through government unemployment insurance programs. ${ }^{39}$ The primary problem with a worker attempting to insure privately against this risk is "moral hazard": ${ }^{40}$ an insurer could not be certain that a worker had not subtly but intentionally brought about his or her own job loss. Nor can workers diversify effectively, because "a worker cannot easily put small bits of his effort into a large number of different jobs." 41 Virtually all jobs require a substantial portion of the worker's waking hours. ${ }^{42}$

In short, workers not only bear part of the risk of the enterprise-particularly in troubled economic times and in declining industries-but they also are much less able than investors to reduce

37 "Total economic independence" is the ability to live independently of the economic system. A laid-off worker cannot go live off of the land-by farming and hunting-with little or no investment. Workers thus are more subject to cyclical downturns such as recessions than are shareholders.

38 See K. Arrow, Essays In the Theory of Risk-Bearnig 135 (1971); Meade, supra note 20 , at 426 .

39 See C. Azariadis, Implicit Contracts and Related Topics: A Survey 3 (Nov. 1979) (unpublished paper in the University of Pennsylvania's Lippincott Library). Cf. WILLIAMson, supra note 18 , at 70 ("That ... workers .... as a group, can pool risks only with difficulty seems evident. ..."). The government can only insure workers to a limited extent because it faces the same problem private insurers facemoral hazard. See infra note 40 \& accompanying text.

40 See K. ARrow, supra note 38, at 142-43, 202-03; C. Azariadis, supra note 39, at 3. Moral hazard stems from the ability and willingness of workers to misrepresent information and intentions to further their self-interest. It derives from an asymmetric distribution of information: only the worker can verify whether she/he worked to the best of his or her ability, or whether the layoff was in part a result of poor work or even intentional. Wrrramson, supra note 18, at 31-33.

41 Meade, supra note 20, at 426.

42 Companies require substantial commitment by the worker because the firm otherwise incurs three kinds of costs: set-up costs-the lessened efficiency of work at the beginning and end of a shift-job-specific training costs, see WullaMson, supra note 18, at 62-63, and administrative costs. Thus, it is more efficient, everything else being equal, for fewer workers to work longer hours than for many workers to work a few hours apiece. Obviously, a point of diminishing returns beyond which this proposition no longer holds true will be reached because worker productivity will decrease with fatigue.

There are also reasons why a worker would prefer to spend most or all of his hours working at one job. The most important reason is the cost of transportation and lost time involved in moving from one job to another. In addition, jobs for which part-time work is available often involve low-skilled work with low pay rates. 
their risk through direct or indirect diversification. ${ }^{43}$ Hence, the argument for giving corporate control to suppliers of capital because they bear the risk of the enterprise is seriously flawed. ${ }^{44}$ Indeed, the distribution of risk in the modern public corporation suggests that some worker representation on the board of directors would be appropriate on grounds of both efficiency and equity.

\section{The Economics of Contractual Governance}

Optimizing the efficiency of supply of different productionprocess inputs-labor, raw materials, and component parts-requires the adoption of appropriate organizational forms and governance structures for contractual relationships. ${ }^{45}$ Relations to sources of inputs may vary from classical arms-length "spot-market" contracting-in which each transaction is discrete, requiring no past or future relationship, and takes place at a market-defined price-to vertical integration, in which the corporation merges with the source of supply. ${ }^{46}$ Between these two extremes is a range of alternatives.

Professor Oliver E. Williamson has developed a rudimentary general theory that describes the effects of three important variables on the efficient governance structure for relationships like those between producers and input suppliers. ${ }^{47}$ According to this framework, the most efficient form of contractual governance for a specific relationship depends on three dimensions: (1) "the degree to which durable transaction-specific investments are incurred"; (2) the frequency with which transactions recur; and (3) uncertainty. ${ }^{48}$ In this section, Professor Williamson's analytic framework is described and then applied to labor-management relations.

43 Insurance is an indirect form of diversification. See supra text accompanying note 39 . The insurance company diversifies its risks by pooling a large number of uncorrelated risks together. See K. ARRow, supra note 38, at 200-01.

44 Given an awareness that workers bear a significant share of the risk of the enterprise, it becomes very difficult to assess qualitatively the relative sizes of the risks borne by investors and workers in a specific corporation. These relative sizes would depend on the dollar values and probabilities of the potential losses, the degree of diversification, and the degree of risk aversion of each group. For an interesting viewpoint on this last factor see F. KNIGHr, supra note 8, at 269-70 (suggesting that entrepreneurs are "confident and venturesome" and that employees are "doubtful and timid").

45 Williamson, Transaction-Cost Economics: The Governance of Contractual Relations, 22 J.L. \& Econ. 233, 235 (1979).

46 This example of vertical integration would fall into a category of corporate form that Williamson calls "unified governance." Id. 253. Both "parties"-manufacturer and supplier-are under the same governance structure. For a more extensive discussion of the unified governance structure, see infra section II C 3 .

47 Williamson, supra note 45 , at 233 .

48 Id. 239. 


\section{The Three Dimensions of Contractual Governance}

\section{a. Transaction-Specific Investments}

A durable transaction-specific investment is a long-term investment whose value in other uses is "much smaller than [in] the specialized use for which it has been intended," 49 and whose cost may only be recouped over an extended period of time in the intended use. Where such investments have been made, "the specific identity of the parties has important cost-bearing consequences." 50 For example, a supplier who purchases expensive specialized equipment or builds a new plant in a particular location in order to suit a particular manufacturer's needs may be "effectively 'locked into" the transaction to a significant degree" 51 because his equipment or location is poorly suited for supplying other companies. If the manufacturer cannot costlessly turn to alternative suppliers, the effect is symmetrical, and the manufacturer also is committed to the relationship. ${ }^{52}$

Employment relationships frequently involve investments in human assets that are transaction-specific. Employees become more valuable to the employer as they acquire job-specific knowledge and skills through specialized training and learning-by-doing. ${ }^{53}$ Hence, if an employer makes a substantial transaction-specific investment that is symmetrical because the employees cannot use the acquired skills as well in other jobs, both the employer and the union will have an interest in forging a close and continuing relationship. A breakdown in such a relationship-for example, a plant-closing because of a long-term inability to agree to employment termsnormally will entail a loss in efficiency as the workers move to other

49 Id. 240.

$50 \mathrm{Id}$. (emphasis in original).

$51 \mathrm{Id}$.

$52 I d$.

53 See WrLramson, supra note 18, at 62-63; Williamson, supra note 45, at 240. See generally P. Doennnger \& M. Pione, Internal Labor Markets and Manpower ANALYsis 13-17 (1971).

The value to the employer of such job-specific knowledge and skills derives from their economizing propensities with respect to "task idiosyncracies," which

can arise in at least four ways: (1) equipment idiosyncracies, due to incompletely standardized . . . equipment, the unique characteristics of which become known through experience; (2) process idiosyncracies, which are fashioned or "adopted" by the worker and his associates in specific operating contexts; (3) informal team accommodations, attributable to mutual adaptation among parties engaged in recurrent contact ....; and (4) communication idiosyncracies with respect to information channels that are of value only within that firm.

Writamson, supra note 18 , at 62 . 
employment opportunities in which their value is less because the job-specific knowledge and skills are useless.

\section{b. Recurrence of Transactions}

Professor Williamson's second variable is the frequency of the transaction. When transactions are discrete, the costs of negotiating and setting up a private contractual governance structure will normally outweigh any benefits that might derive from such an arrangement. When transactions are continual or recurrent, however, these costs may be spread over many transactions, and thus are less likely to outweigh the benefits of a private governance structure.

In the employment relationship, the workers and the employer are engaged in a continuous process of labor supply and demand. Because this Comment is concerned only with these recurrent transactions, the analysis below will ignore the governance of discrete transactions, and will discuss the effects of changes in the other two variables only.

\section{c. Uncertainty}

The third parameter affecting the efficiency of particular organizational forms is uncertainty of future events and economic conditions. No labor agreement can provide for all future contingencies, because of both the limited ability of the parties to define all possible future conditions and to specify their agreement precisely, and the high cost of the extended negotiations that would result if the parties had to discuss and agree on all conceivable contingencies. Grievance and arbitration procedures and appropriate legal standards provide a flexible governance structure for defining rights and responsibilities in many situations not provided for by the terms of the labor contract. As the degree of uncertainty increases, however, a relationship relying primarily on contractual provisions will experience severe strains in attempting to adapt to unforeseen situations.

This strain results from each party's attempts to obtain whatever incremental gains can be acquired from the unprovided-for situation and to shift any unexpected costs onto the other party. Professor Williamson denotes this problem "opportunism."

Although both parties have a long-term interest in effecting adaptations of a joint profit-maximizing kind, each also has an interest in appropriating as much of the gain as he can on each occasion to adapt. Efficient adaptations 
which would otherwise be made thus result in costly haggling or even go unmentioned, lest the gains be dissipated by costly subgoal pursuit. . Governance structures which attenuate opportunism and otherwise infuse confidence are evidently needed. ${ }^{4}$

\section{Efficient Governance Structures}

The appropriate governance structure for any particular transaction depends upon the dimensions of the three variables outlined above. For the recurring relationships with which this Comment is concerned, the available alternatives span a spectrum rather than exist as discrete organizational forms. For supply contracts for a fungible good like cotton, the availability of legal redress in the courts and of alternative sources of supply will usually suffice to mitigate opportunistic behavior. At the other extreme, the appropriate governance structure may be unified, as with an electrical utility that finds it necessary to expand backwards into coal mining to ensure a regular supply of fuel. More generally, unified governance means that "the transaction is removed from the market and organized within the firm subject to an authority relation." 55 The most efficient governance structure approaches unified governance when the two remaining variables-uncertainty and investment-specificity-are high, indicating that a strong bond between the parties is needed.

Professor Williamson has applied the label "bilateral governance" to the broad middle ground between the extremes of market contracting and unified governance. Williamson's prototype of this form of governance is collective bargaining and the entire labor-management relationship. ${ }^{56}$ Bilateral governance provides a mechanism for some joint contract-term decisionmaking flexibility, ${ }^{57}$ but this flexibility ultimately is limited by the explicit terms of the agreement.

An example will help to illustrate the relationship between the alternative governance structures and the two variables with which we are primarily concerned, which can be divided into three rough dimensions for analytical purposes: high, intermediate, and low. Assume that two parties are planning a recurrent input-supply relationship that involves both a highly transaction-specific invest-

54 Williamson, supra note 45 , at 242 (emphasis added).

55 Id. 250.

56 Williamson, supra note 18, at 72-76; see Williamson, supra note 45, at 250 .

57 The "combination" between employer and union can be seen intuitively in such mechanisms as grievance panels for handling employee complaints that are staffed by union and employer representatives. 
ment-such as the construction of a plant that has no other economically feasible use because of its location or design-and intermediate uncertainty. The appropriate governance structure for this highly transaction-specific investment in a recurring relationship from the standpoint of societal economic efficiency necessarily would be more complex than simple market contracting, because any rupture in the relationship would result in the loss of the transaction-specific investment, which would be a waste of scarce economic resources. ${ }^{58}$ Furthermore, the party who would have to make the transaction-specific investment will refuse to agree to do so if the other party would remain free to end the relationship at will during any dispute. Conversely, both parties may balk at submitting to a long-term relationship in which either one may seek to take advantage of the other's inability to leave at will. In such circumstances, the parties may seek to design a flexible governance structure that leaves room for contract-term decisionmaking, yet provides some assurances against opportunistic behavior. In an extreme case, the cost and imperfect operation of bilateral governance may make it more efficient for the parties to merge, because an economical relationship may otherwise fail to materialize because of contracting difficulties.

High uncertainty reinforces the tendency toward a unified governance structure. If the contractually unprovided-for event were to occur frequently because of rapid changes in the economy or industry, then a bilateral governance structure might collapse because of frequent, costly haggling and mistrust. Unified governance allows sequential adaptation to changes in the market or economy, unconstrained by the terms of even a relatively flexible contract, and thus helps to mitigate the impact of uncertainty without allowing one party to gain at the expense of the other.

Both of these variables need not be high, however, for unified governance to be the most efficient organizational structure, according to Professor Williamson's model. First, if the transactionspecific investment is not symmetrical, that is, if only one of the parties is to make such an investment, the party making that investment will be at a serious bargaining disadvantage during the contract term. The party making the transaction-specific investment

58 Incentives for market trading or other governance structures weaken as the transactions become progressively more specialized from the transaction-specific investment. "The reason is that, as the specialized human and physical assets become more specialized to a single use, and hence less transferable to other uses, economies of scale can be as fully realized by the buyer as by an outside supplier." Williamson, supra note 45 , at 252 (footnote omitted). The choice then becomes unified governance because of its "superior adaptive properties." Id. 252-53. 
will be subject to the ill effects of the other party's opportunism, because the benefits to that party are contingent upon continuing execution of the relationship. ${ }^{50}$ Unified governance can attenuate opportunism in such circumstances, and thus save resources that otherwise would be expended on negotiation or litigation, or facilitate an agreement that would not otherwise be reached.

The second situation in which unified governance is the optimal structure, according to the Williamson model, is when either investment specificity or uncertainty is of an intermediate degree and the other variable is at a high level..$^{60}$ In such cases, the degree of investment specificity and uncertainty is high enough to create a very serious potential for opportunistic behavior, and potential contractual parties will normally be unable to agree to anything short of unified governance in order to continue the relationship.

\section{Application to the Labor-Management Context.}

Professor Williamson characterizes the typical collective-bargaining relationship as one of bilateral governance with an intermediate degree of both investment specificity and uncertainty. ${ }^{61}$ As this Comment has explained, the most efficient governance structure in such a situation may be closer to unified than to bilateral governance if investment specificity is asymmetrical or if either uncertainty or investment specificity shifts from an intermediate to a high level.

\section{a. Asymmetric Investment}

It is quite possible that employers make greater transactionspecific investments than do workers. Corporations invest in the truining and on-the-job skill acquisition of their workers. The workers, however, may be able to transfer these skills to alternative jobs. In industries such as automaking that have strong unions and large corporations, however, the investment asymmetry is probably not great. The level of the skills obtained from training and from learning-by-doing is probably not such that training replacements would be a major investment for an automaker and, therefore, would require a stronger bond with the union. The skills imparted may be acquired too easily to pose a problem for the employer.

59 Id. 241.

60 Id. 252-54.

01 The recurrence of the transaction variable will not be discussed because, in the context of this Comment, the transactions are always recurring. 


\section{b. High Investment Specificity}

High investment specificity is probably unlikely in the context that this Comment addresses. Such investment means that the employee has acquired unique skills valuable to the employer. Yet, "most of these individuals could move to another organization without significant productivity losses." 62 Moreover, unified governance in this context would require "merger" between the corporation and the individual employees, but "limits on indenture foreclose this option for labor-market transactions." ${ }^{63}$ A corporation cannot "buy" a uniquely qualified employee, and ordinarily the employee is not able to purchase the corporation. Because most investment germane to this Comment is of an intermediate degree, ${ }^{64}$ however, this situation is not particularly relevant.

\section{c. High Level of Uncertainty}

A high level of uncertainty is the most plausible rationale for a need to shift from bilateral governance to some form of unilateral governance. Instability that is either general to the economy or specific to an industry or corporation may combine with the union's mistrust of management assertions concerning the firm's economic state and prospects, the necessity for austerity measures, or the degree to which management is sharing in such measures. Higher uncertainty also may be a natural result of the increasing size of corporations and the complexity of our economy. As corporations diversify into many different fields and decide-at management levels far removed geographically and hierarchically from the shop floorto shift capital resources from one plant to another or one industry to another, workers' sense of insecurity may justifiably increase.

Uncertainty thus may grow to a high enough level to warrant a closer step to unified governance; Professor Williamson states that "bilateral governance structures will often give way to unified ones as uncertainty is increased." ${ }^{65}$ The corporation and the union alike may need unified governance to ensure that the maximum benefits resulting from transaction-specific investments are accrued

62 Id. 257. This also, however, may indicate that the specific investment was asymmetrical. Athletes and artists, for instance, would fall into the category the quote addresses. In either case, unified governance in the high specificity situation is not usually applicable to the environment examined by this Comment.

63 Id.

64 This is implicit in Williamson's discussion of collective bargaining in a section on "[m]ixed [t]ransactions." Id. 255-57.

65 Id. 254. 
and that the relationship is close enough to weather difficult times and unforeseen events.

\section{Unified Governance in the Collective Bargaining Context}

Interpreting what unified governance would look like in the labor-management context is difficult. Although Professor Williamson provides a general description of unified governance, ${ }^{66}$ he says little about the labor market context. ${ }^{67}$ "Merger" in the sense of corporate takeover of the union of course would be totally abhorrent to our labor law and policy. ${ }^{68}$ Moreover, direct employee ownership of the corporation raises serious economic questions, even if it were otherwise feasible. ${ }^{69}$ Union representation on the corporation's board of directors, however, provides an approximation of unified governance without sacrificing our national labor policy. ${ }^{70}$ Thus, given the high degree of uncertainty in today's complex and interdependent economic system, the most efficient

66 See supra text accompanying note 55.

07 Williamson saw unified governance as viable for labor/management only in the high uncertainty, intermediate investment specificity case. See supra text accompanying notes 62-65. Unified governance in the high investment specificity situation might approximate "complex contracts designed to tie the interests of the individual to the organization on a long-term basis ...." Williamson, supra note 45 , at 257 , but the ultimate expression of unified governance in the labor-market context would be employee or union ownership. For conflicting formal analyses of the economic merits of worker ownership, see the articles cited supra note 20 .

68 One might well ask why unified governance should imply union representation rather than direct employee representation. Conceptually, unified governance is best seen as an extension of bilateral governance (collective bargaining). See supra text accompanying note 56 . Thus seen, it would involve the parties to the collective agreement: the corporation and the union.

There are also some practical reasons supporting this role for the union. First, a union representative would have the resources of the union at his disposal, making him a more effective representative. Second, union representation would allow better coordination of the representative's and the union's decisionmaking, so that they would not work at cross-purposes. See Summers, Codetermination in the United States: A Projection of Problems and Potentials, 4 J. Comp. Conp. L. \& SEC. Rec. 155, 184-85 (1982). Finally, union leaders are more experienced at negotiating with top corporate officials, and hence would not be subject to the combination of awe and fear that might hinder a worker discussing issues with corporate directors for the first time. For an illuminating analysis of the kind of shop organization that would be needed to allow effective worker representation in nonunionized firms, see Summers, supra at 160-63.

69 See supra note 20 . The problems workers face in attempting to shift the risk of corporate failure would take on greater seriousness if the magnitude of the risk increased. See supra section II B 2.

${ }^{70}$ See Labor Management Relations [Taft-Hartley] Act, $\$ 8(a)(2), 29$ U.S.C. $\$ 158(a)(2)(1976)$ (prohibits too close an interaction between union and employer so that neither domination nor collusion results to the detriment of the workers). 
corporate organization form, at least in some sectors, may include union representation of worker interests on the board of directors. ${ }^{71}$

\section{Worker Representation and Organizational Slack}

Substantial empirical evidence suggests that corporate bureaucracies do not operate as efficiently as they could. This inefficiency has several causes, some of which are internal and some external to the corporation. Union representation may help to reduce these pervasive sources of inefficiency.

\section{Internal Causes of Inefficiency}

\section{a. Organizational Slack}

One cause of inefficiency in large corporations is endemic to the bureaucracy qua complex organization. A great mass of literature concerning complex organizations demonstrates that complex organizational forms inevitably breed unintended consequences. ${ }^{72}$ These consequences stem from such phenomena as subgoal pursuit, ${ }^{73}$ information impactedness, ${ }^{74}$ uncertainty absorption, ${ }^{75}$ and specialization of communication functions. ${ }^{76}$ Although the resulting "organizational slack" can be limited, it cannot be totally eliminated.77

71 The degree of uncertainty necessary to make union representation more effcient than strict bilateral governance is uncertain. It could be argued that the nature of large corporation collective bargaining is such that union representation is always appropriate. Conversely, it could be argued that only a substantial shortterm probability of firm bankruptcy is sufficient. In any case, what is appropriate for one firm or industry would not be necessarily appropriate for another.

The best approach for a court faced with this quandry is to let the parties decide, because they are in the best position to know. See supra text accompanying notes 28 \& 31 (suggesting a presumption of efficiency when the union and the appropriate corporate agents agree to union representation).

72 See generally J. March \& H. Simon, Organizations 36-47 (1958).

73 "Subgoal pursuit" refers to optimization of an incomplete subset of an organization's goals or of a subunit's (an individual's or department's) goals at the expense of the total organization. "Subgoals may replace broader goals as a part of the whole process of replacing a complex reality with a simplified model of reality for purposes of decision and action ...."Id. 157 (citation omitted). Subgoal pursuit may also result from opportunistic behavior by individuals not fully committed to organizational goals. See O. Wurramson, supra note 18 , at 125.

74 "Information impactedness" refers to the combination of asymmetric distribution of information-when only one (or a subset) of the parties to a transaction can verify purported facts, giving those parties an incentive to make misrepresentations-and opportunism, a willingness to manipulate information and misrepresent intentions. O. WIIIIAMSON, supra note 18, at 31-33.

75 Uncertainty absorption occurs "when inferences are drawn from a body of evidence and the inferences, instead of the evidence itself, are then communicated." J. MARCH \& H. Simon, supra note 72, at 165.

76 Id. 166-69. "The existing pattern of communication will determine the relative frequency with which particular members of the organization will encounter particular stimuli, or kinds of stimuli, in their search processes. . ." Id. 168.

77 See generally J. MARCH \& H. SrMon, supra note 72, at 36-47, 169-71. 
Moreover, because the basic cause of the inefficiency is the structure itself rather than, for example, the specific personnel chosen, the inefficiency normally can be limited only by introducing structural modifications. ${ }^{78}$

\section{b. Director Ineffectiveness}

A second, related cause of inefficiencies in large corporations is the inability of the board of directors, which in theory represents the interests of the shareholders, ${ }^{79}$ to supervise managerial actions effectively. ${ }^{80}$ This problem is at least partly structural in nature; given the complexity of the organization and its environment, ${ }^{81}$ directors do not have the time or other resources necessary to make independent judgments concerning corporate policy. ${ }^{82}$ It also may be in part a matter of the type of individuals chosen as directors. Most directors come from a narrow social class that may tend to be unduly sympathetic to management. ${ }^{83}$

\section{External Causes: Capital Market Failure}

Neither of these two internal sources of inefficiency could result in major distortions except in conjunction with the failure of the capital markets to provide an effective check against internal management inefficiency. ${ }^{84}$ Theoretically, the capital markets, through threat of takeover, should preclude substantial management inefficiency. ${ }^{85}$ Real capital markets, unfortunately, fall short

$78 \mathrm{Cf}$. O. Wurramson, supra note 18 , at 117-51 (discussing the transactional limitations on firm size without changes in organizational form).

79 See supra text accompanying notes 9-12.

80 See, e.g., M. MACE, DIRECTORs: MYTH AND ReaLITY (1971); Solomon, Restructuring the Corporate Board of Directors: Fond Hope-Faint Promise?, 76 Mrck. L. Rev. 581, 583-91 (1978). But cf. Eisenberg, Legal Models of Management Structure in the Modern Corporation: Officers, Directors, and Accountants, 63 CAIIF. L. REv. 375, 438 (1975) (arguing that the board could monitor management effectively given an appropriate organizational structure).

81 See supra text accompanying notes 72-76.

82 Solomon, supra note 80 , at 585-86.

83 Solomon, supra note 80 , at 584-85. This problem is actually an indirect result of the structural problems. See supra text accompanying notes 81-82. If shareholders had the time, determination, and informational resources necessary for them to make informed decisions independent of management's recommendations, management would not be able to install "people who are economically and psychologically sympathetic, if not indebted, to the chief executive officer and who are therefore disinclined to challenge him." Solomon, supra note 80, at 584 .

84 See generally F. Scherer, supra note 28, at 37-38; O. WrLtamson, supra note 18 , at $141-43$.

85 E.g., F. Scherer, supra note 28 , at 37 ; O. WritaMson, supra note 18 , at 141. Stockholder suits are another potential limitation on managerial discretion, id. 142, but are subject to the same problems as the takeover threat, see infra text accompanying notes 87-89. See also Bishop, Sitting Ducks and Decoy Ducks: New 
of this frictionless ideal: "[T]he available evidence provides at best only weak support for the hypothesis that takeovers generate an effective disciplinary mechanism against departures from profit maximization." 86

This gap between theoretical ideals and practical reality results from two types of transaction costs: information impactedness ${ }^{87}$ and takeover costs. Information impactedness limits the ability of takeover agents and shareholders to assess the degree of management inefficiency, and thus diminishes the willingness of the takeover agents to attempt takeover and of shareholders to believe the claims of such agents in takeover attempts. ${ }^{88}$ The second type of transaction cost, the actual cost of the attempted takeover, includes the costs of convincing shareholders about management inefficiency and possible litigation costs. ${ }^{59}$ The combination of these two types of transaction costs will lead potential takeover agents to ignore otherwise attractive takeover opportunities, and thus limits the ability of the capital markets to check management inefficiency.

\section{Union Representation's Impact on Management Inefficiency}

Union representation could reduce the inefficiency resulting from organizational complexity, board-of-director ineffectualness, and capital market distortions. The ability of the board of directors to monitor management would be reduced by the union director's use of intra-union communication channels to provide an additional ongoing source of information to the board.90 Such an informational source potentially could be quite productive, even if the shareholder directors are suspicious of the information supplied.

Trends in the Indemnification of Corporate Directors and Officers, 77 Y $\mathrm{ALE}$ L.J. 1078, 1095-1103 (1968).

86 F. SCHERER, supra note 28 , at 38 ; cf. O. WILLIAMson, supra note 18 , at

142 ("[ $t]$ raditional capital market controls are relatively crude . . . ").

87 See supra note 74.

$88 \mathrm{O}$. WILLIAMSON, supra note 18 , at 142.

89 Id. $142-43$.

90 Economist Arthur F. Burns, former chairman of the Federal Reserve Board, has pointed to a different communications impact as underlying his support of union representation: "We want to educate some of these labor leaders . . . . I work on the theory that, by sitting in on board meetings and studying the company's affairs, they will learn something about the company's needs and problems . . . "New York Times, Apr. 27, 1980, $\$ 3$, at 14, col. 3-4. Both of these kinds of communications effects have been found by a government commission studying codetermination in West Germany. See Note, Employee Codetermination: Origins in Germany, Present Practice in Europe, and Applicability to the United States, 14 Harv. J. L.EGrs. 947, 960 (1977). See generally Summers, supra note 68, at 156-57, 183. 
At a minimum, the union-provided information, when it conflicted with information provided by management, would alert the shareholder directors to the need to take care in making important decisions. At times, the union-provided information could have a much greater impact, by illustrating the logical or practical flaws in the management's reasoning.

Union directors also could help to check management inefficiency because they could devote considerably more time to board matters than independent outside directors, and because they would not have the same sympathy for management as members of the "closed club of elites." 91 Finally, union directors, because of their independence, could bring to bear on management the threat of communication of managerial failings to two constituencies-the workers and the shareholders. In each of these ways, union representation might result in a significant increase in management efficiency.

\section{E. Summary: The Economics of Union Representation}

This section's economic analysis provides a plausible, though necessarily qualitative, argument for allowing union representation on corporate boards when agreed to as a product of collective bargaining. Such representation based on voluntary agreements generally would have beneficial efficiency consequences. Union representation woüld result in a more appropriate correspondence between corporate control and risk-bearing and would lower transaction costs in the governance of the relationship between the union and the corporation. In addition, union representation could reduce inefficiencies resulting from organizational complexity, boardof-director ineffectualness, and capital market failure.92

91 Solomon, supra note 80 , at 586.

92 The successful West German experience with codetermination provides at least some support for the conclusions of this section despite two important differences from the type of representation contemplated in this Comment: its compulsory character in Germany and the bilevel German corporate board structure, with mandatory worker representation solely on the upper, supervisory board. See generally Note, supra note 90, at 949-62. According to a board chairman in the West German steel industry, codetermination "is definitely a system of conflict disentanglement and conflict resolution that is of great benefit to the development of our industry and our economy." Id. 959 n.32 (originally quoted in Busness INTERNATIONAL, INDUSTRIAL DEMOCRACY IN EUROPE 34 (1974)). A West German government commission has found that codetermination has resulted in facilitation of labor-management communication, greater labor-management cooperation, increased employee job security; and reduced industrial strife. Id. 960 (footnotes omitted). 


\section{UnION REPRESENTATION, Collective BaRgaining, AND THE NATURE OF the CoRporation}

The preceding analysis has developed a strong economic rationale for union representation on corporate boards. It is now necessary to assess the compatibility of union representation with important noneconomic policies. The next two sections examine the institutional compatibility of union representation with the process of collective bargaining and with our legal model of the corporation.

\section{A. Industrial Stability, Democracy, and Collective Bargaining}

Union representation on corporate boards is consonant with the policies underlying our labor laws as they have been interpreted and developed over the past forty years. As Congress declared in the National Labor Relations Act, the legislation addressed a situation that could

lead to strikes and other forms of industrial strife or unrest, which have the intent or the necessary effect of burdening or obstructing commerce. ...

Experience has proved that protection by law of the right of employees to organize and bargain collectively ... promotes the flow of commerce by removing certain recognized sources of industrial strife and unrest, by encouraging practices fundamental to the friendly adjustment of industrial disputes. . . . .

Since the National Labor Relations Act's enactment, stability of industrial relations has been a frequently mentioned guiding policy for courts to follow. Thus, for example, as arbitration became "the substitute for industrial strife," 94 the employer's agree-

93 National Labor Relations Act $\$ 101,29$ U.S.C. $\$ 151$ (1976). See also the Labor Management Relations Act $\$ 1,29$ U.S.C. $\$ 141$ (1976):

Industrial strife which interferes with the normal flow of commerce and with the full production of articles and commodities for commerce, can be avoided or substantially minimized if employers, employees, and labor organizations each recognize under law one another's legitimate rights in their relations with each other. ...

It is the purpose and policy of this chapter, in order to promote the full flow of commerce, to prescribe the legitimate rights of both employees and employers in their relations affecting commerce, to provide orderly and peaceful procedures for preventing the interference by either with the legitimate rights of the other. . . . (1960).

24 United Steelworkers v. Warrior \& Gulf Navigation Co., 363 U.S. 574, 578 
ment to arbitrate was interpreted as the quid pro quo for the union's agreement not to strike. ${ }^{9 \bar{s}}$ This judicial interpretation "expresse[d] a federal policy . . . that industrial peace can best be obtained only in that way." 98 The collective bargaining process consistently has been the judiciary's method of ensuring industrial stability. ${ }^{97}$

Collective bargaining also represents another fundamental policy. The social and political movement that led to the emphasis placed on collective bargaining in our labor laws began as a general movement for industrial democracy. ${ }^{98}$ Indeed, "[ $\left.t\right]$ he theme that our system of political democracy should be matched by a system of industrial democracy has been an irrepressible one in our history." 99 This can be seen in the oft-quoted words of Louis D. Brandeis:

The end to which we must move is a recognition of industrial democracy as the end to which we are to work. . . . There must be a division not only of the profits, but a division of responsibilities; and the men must have the opportunity of deciding, in part, what shall be their condition and how the business shall be run. ${ }^{100}$

Union board representation of employees is not a substitute for the collective bargaining process. Rather, it serves as a com-

05 See Textile Workers Union v. Lincoln Mills, 353 U.S. 448, 455, 458 (1957) ("Plainly the agreement to arbitrate grievance disputes is the quid pro quo for an agreement not to strike. . . [T] [ Norris-LaGuardia Act does, indeed, indicate a congressional policy toward settlement of labor disputes by arbitration ....").

96 Id. 455.

97 See, e.g., United Steelworkers v. Warrior \& Gulf Navigation Co., 363 U.S. at 578 ("The present federal policy is to promote industrial stabilization through the collective bargaining agreement.") (footnote omitted).

98 See Sunmers, Industrial Democracy: America's Unfulfilled Promise, 28 CrEv. ST. L. REv. 29, 29-30 (1979).

39 Id. 29 (footnote omitted).

100 Testimony of Louis D. Brandeis before the Commission on Industrial Relations. U.S. Commission on Industrual Relations, Flival Report of the COMatrssion on Industrial Relations 81, 83-84 (1915), quoted in Summers, stipra note 98, at 32 (emphasis added). According to Professor Wellington,

The production line is emasculating, and thus the quest must be to restore manhood to man. It is dehumanizing, and thus the worker must again be made human. It is uncreative, and thus the man at his machine must be given a creative outlet. Participation in industrial government is a way to achieve these goals.

H. Welington, Labor and the Legal Process 26-27 (1968). Note that Professor Wellington refers to "[p]articipation in industrial government," not more specifically to collective bargaining, as a way to achieve these goals. Id. 27. See also P. Blumberc, Industrual Democracy 123 (1968) ("There is hardly a study in the entire literature which fails to demonstrate that satisfaction in work is enhanced... from a genuine increase in workers' decision-making power."). 
plement to ${ }^{101}$ and an extension of an institutional process that has changed significantly since its origin. Collective bargaining has been marked by greater centralization and consolidation; ${ }^{102}$ the scope of bargaining has expanded to encompass matters formerly considered management prerogatives; ${ }^{103}$ and accommodation and cooperation increasingly have replaced confrontation. ${ }^{104}$ Illustrative of this last development is the growing use of joint labormanagement committees to deal with a wide array of problems. ${ }^{105}$

Union board representation is both a logical culmination of these developments ${ }^{106}$ and a further expansion of union influence into what previously was regarded as management's domain. Board representation would provide the union with direct input into decisions presently beyond the pale of collective bargaining. ${ }^{107}$

Unlike an expansion of the scope of collective bargaining, however, union representation would engender a cooperative rather than an adversarial relationship. ${ }^{108}$ Because of its adversarial nature, the collective bargaining process "may not always represent

101 Professor Summers suggests that

probably the most significant impact of codetermination on collective bargaining would be to provide the union with information concerning the enterprise that it could use when developing its bargaining policy. . . Union access to this information ... would not interfere with, but would enhance, good faith bargaining. . . . Collective bargaining would become less a poker game and more a process of solving real problems.

Summers, supra note 68 , at $165-66$.

102 For example, certain industries now bargain on an industrywide basis. The unions in such industries make a collective bargaining agreement with a single employers association instead of company by company within the industry.

${ }^{103}$ See, e.g., Fibreboard Paper Prods. Corp. v. NLRB, 379 U.S. 203 (1964) (subcontracting).

104 A. Ammutx, Worker Participation in Management Decision-Manking in Western Europe 32 (Cong. Res. Serv. Rep. No. 79-136E, Apr. 23, 1979).

$105 \mathrm{Id}$. 33. See generally id. 33-41.

106 See Note, supra note 90 , at 987-91.

107 See, e.g., First National Maintenance Corp. v. NLRB, 452 U.S. 666 (1981)

(no duty to bargain over partial plant closings); N.Y. Times, Nov. 26, 1979, at D1, col. 1 (plant closings).

108 See Note, supra note 90 , at 988.

Professor Summers argues that:

[T] he form and language of confrontation obscures the mutuality of interest between employees and employer. . . Representation on the board can help employees recognize these mutual interests, and by providing them with more complete and reliable information concerning the profitability and prospects of the enterprise it can make them more ready to accept terms at the bargaining table that will promote the common long-run goal of success of the enterprise.

... Confrontation might well be significantly reduced at the bargaining table, and this would modify the character of collective bargaining. Not everyone would count this a loss.

Summers, supra note 68 , at 164 . 
the most "effective means of insuring that the employee viewpoint is taken into account in the formulation of basic corporate policies ...." 109 Although the adversarial posture of collective bargaining appropriately reflects the directly conflicting interests of workers and shareholders with respect to wages and some other basic issues, the more cooperative orientation of union representation would be more appropriate where worker and shareholder interests conflict less completely. ${ }^{110}$ Moreover, because the issues addressed on the director level often are not discussed during the bargaining process, the more cooperative nature of union board representation may be the only way for the worker viewpoint ever to be considered by a nonreceptive management. Thus utilized, union representation would complement effectively the workings of the collective bargaining process.

\section{B. Union Representation and the Nature of the Corporation}

The traditional view of the publicly-held company is that it is a maximizer of shareholder stock value, ${ }^{111}$ and that the directors of the company should represent the interests of the shareholders, whose pecuniary fates are in the hands of management. This conception of the corporation is unsound. The proposition that shareholders even indirectly manage the publicly-held corporation has little empirical support. ${ }^{112}$ It is, moreover, appropriate that the shareholders lack plenary control, because shareholders are less in need of protection than are other groups. ${ }^{113}$

\section{$100 \mathrm{Id}$.}

110 For example, these interests may be more consonant with respect to overall productivity or quality control improvements. According to Professor Summers:

There is little danger that codetermination will detract from or undermine collective bargaining. Instead, codetermination will supplement collective bargaining and can strengthen and improve it. The real danger runs in quite the other direction-that the confrontation attitudes of collective bargaining will be carried into the board room and frustrate codetermination.

Sưmmers, supra note 68, at 166.

111 See, e.g., T. HIRSHLEIFER, supra note 22, at 229 ("In the traditional formulation, the firm is said to maximize profit . . . to attract the resources [of shareholders].") (emphasis in original).

112 Stockholders generally are in a very poor position to govern. The individual shareholder may have only a small percentage of the corporation's stock. In addition, the shareholder's portfolio may contain so many different companies' stocks, for the purposes of diversifying away risks of monetary loss, that she/he has little interest in corporate governance. The cost of becoming well-informed may exceed greatly the benefits. See M. MACE, supra note 80, at 68-69. See generally Solomon, supra note 80 , at 583-87.

i13 See supra section IIB; Chayes, The Modern Corporation and the Rule of Law, in The Corporation IN Modern Society 40 (E. Mason ed. 1959) ("The 
Large corporations have a pervasive influence ón our society:

The modern stock corporation is a social and economic institution that touches every aspect of our lives; in many ways it is an institutionalized expression of our way of life. During the past 50 years, industry in corporate form has moved from the periphery to the very center of our social and economic existence. Indeed, it is not inaccurate to say that we live in a corporate society. ${ }^{114}$

The validity of this statement by the then vice-president and general counsel of Ford Motor Company has only increased in the 23 years since it was made. "It follows that ... [corporations] bear large responsibility for the quality and tone of American life." 115 Corporations certainly have an impact beyond shareholders alone, yet shareholders are the sole group (other than management) with any evident representation on the board of directors. Reforms proposed to redress this imbalance have included greater emphasis on outside directors ${ }^{116}$ and election of public interest directors by groups other than the shareholders. ${ }^{117}$

market affords [the shareholder] a way of breaking this relation [to the corporation] that is simple and effective. He can sell his stock ...."). Chayes concluded that "[o]f all those standing in relation to the large corporation, the shareholder is least subject to its power. . . Their interests are protected if financial information is made available, fraud and overreaching are prevented, and a market is maintained in which their shares may be sold. Id. 40 .

114 W. Gossetr, Corporate Crtrzenshap 157 (1957); see also Chayes, supra note 113 , at 26 :

Concern with the modern corporation is intensified to the extent that its activities have necessarily ramified beyond the economic sphere of production of goods and service.

Across a widening range of activity, the large corporations have become principal factors. They are the chief agencies of private research. They are the hope of fund raisers for institutions of higher learning and the principal consumers of the products of those institutions. Their advertising supports newspapers and sponsors TV programs. They are a leading, if not the leading, purveyor of influence and pressure on public officials in Washington and state capitals.

See generally C. LINDBLOM, supra note 34 , at 170-88, $201-21$.

115 Chayes, supra note 113 , at 26 . "This attribution of responsibility is not a token of hostility to the large private corporation. What has been said amounts to no more than that the great corporation is the dominant nongovernmental institution of modern American life." Id. 27.

116 See, e.g., Eisenberg, supra note 80, at 404-09.

117 E.g., R. Nader, M. Green \& J. Seligman, Tammg the Gtant Corporation 123-26 (1976); C. Stone, Where the Law ENDS: The Socual Control of CorPORATE BeHavion 152-83 (1975). For other scholarly criticism and proposals, see, e.g., R. NADER, supra; R. Dahl, A Prelude to Corporate Reform, 1972 Bus. \& Soc'Y Rev. 17, 19-20, reprinted in Corporate Sochur Policy 18, 20-21 (R. Heilbroner \& P. London, eds., 1975). Professor Gower refers to the very similar English legal model as "unreal" and "increasingly anachronistic." L. Gower, Gower's Principles of Moderi Compaxy Law 578 (4th ed. 1979) (citation omitted). 
Among the various "disenfranchised" groups affected by cor: porate decisions, workers have the strongest and clearest claim to representation. ${ }^{118}$ Moreover, although worker board representation may be justified on grounds separate from shareholder welfare, ${ }^{119}$ a radical shift from the traditional goal of maximizing shareholder welfare is not necessary to rationalize such representation. The courts can rely on the express vote of the shareholders or their representatives, the board, as an indication that effective union representation is in the shareholders' long-run interests. ${ }^{120}$

In addition, allowing the board to consider the welfare of the corporation's employees is not a radical break from present law. In recognition of the impact of the development of the large modern corporation, the legal structure already has provided for some worker input into corporate affairs: wages, hours, and innumerable working conditions currently are determined through collective bargaining between the union and the corporate management. Furthermore, some courts have been willing to allow boards of directors to make decisions benefiting employees and other groups, at least when such decisions conceivably advanced the shareholders' long-run interests. ${ }^{121}$ Thus, rather than being a complete break with legal tradition, allowing for union board representation of worker interests merely would be a more explicit indication of an emerging conception of the corporation, ${ }^{122}$ a con-

118 L. Gower, supra note 117, at 10-11 (referring to "the undoubted fact that the employees are members of the company for which they work to a far greater extent than are the shareholders ...."); Blumberg, supra note 3, at 553 ("of all the groups affected by the corporation, including the stockholders, it is the employees upon whom the corporation has the most important impact-an impact that is continuous, pervasive and profound."). An incidental benefit of the workers' strong claim is that union representation, unlike that of other groups, including shareholders, can be expected to result in the presence of directors on the board who are not only independent in character but who have the time, determination, and access to independent sources of information necessary for effective supervision of management. See supra note 68 and text accompanying note 91 .

119 See, e.g., Chayes, supra note 113; supra note 117.

120 See supra section II A.

121 See supra notes $9 \& 17$.

122 Among the groups now conceived as outside the charmed circle of corporate membership, but which ought to be brought within it, the most important and readily identifiable is its work-force. It is instructive to cbserve how, almost unconsciously, our legal and political system has worked to give this "constituency" a "say" in the governance of the corporation.

... [w]orkers have organized their own unions. . . This was essentially the structural and institutional invention of the Wagner Act. ... The negotiation of a labor contract can ... fruitfully be seen as an effort to adjust the relations of both parties so that their common ends may be pursued jointly and they will not needlessly interfere with each other in the pursuit of their separate ends. 
ception that recognizes the pervasive influence of corporations on groups other than shareholders, and that therefore allows such other groups to check and channel corporate influence.

\section{The Proposed Standards and Their Application}

This Comment has attempted to demonstrate that union representation is desirable on grounds of economic efficiency, and that it comports well with the traditional and evolving scope of collective bargaining and with the emerging legal theory of the nature of the corporation. The following section will examine what legal standards should govern a union representative on a board of directors and how these standards would best be implemented and applied.

\section{A. The General Standard}

The union board representative's principal fiduciary responsibility should be to the employees in the bargaining unit represented by the union. When employee interests are implicated, the union board director's sole fiduciary duty should be to further those interests. When specific employee interests are not directly involved, however, the union director should have the usual director's fiduciary duty to advance the corporation's interests. Thus, he or she should not be able to ignore corporate interests except when attempting to increase employee welfare. ${ }^{123}$ In particular, a union representative must not be permitted to advance his or her own private interests at the expense of the corporation, unless such advancement is unavoidably incidental to a good faith effort to further worker interests. ${ }^{124}$

Chayes, supra note 113, at 41-42. See also Note, Codetermination in Industry:Why Are They Saying All Those Good Things About It?, 35 U. Tononro FAculty L. REv. 217, 217 (1977):

In its broadest sense, [worker representation] purports to institutionalize the right of employees to have a voice in the making of decisions which affect them. To the extent which our own labour relations law guarantees every person the right to join a trade union which management is compelled to recognize and to negotiate with Canadian employees have the legal right to codetermine decisions relating to the work place (citation omitted).

123 It should be noted that employees and shareholders have concurrent interests in the general financial health of the corporation. It is therefore highly unlikely that a union representative would, in properly carrying out his or her duties, have cause to do substantial injury to shareholder interests. Even a completely worker-controlled firm might require capital investment to continue its existence. To attract such capital, it probably would have to provide a normal return to the investors of capital. Cf. Note, supra note 90 , at 961 (indicating that employee directors in Germany have supported management efforts to increase corporate profitability).

124 Thus, the usual rules with respect to, e.g., usurping corporate opportunities (non-union-related), conflict of interest, and insider trading,- would apply. See 
Employees should be permitted to bring derivative suits in either of two situations. First, if the union representative fails to attempt to advance employee interests that are implicated in board decisionmaking, then a right of action should be available on behalf of the employees. Second, if specific employee interests are not directly involved, the union director should be amenable to suit for any violation of his or her fiduciary duty to further the corporation's welfare, because the employees' welfare is closely, even if indirectly, linked to the corporation's financial health.

In the latter case, unfortunately, the negative impact on the corporation of fraud and other kinds of improper action by a union representative would affect employees only indirectly, and often would not be apparent to them. The harm to shareholders, on the other hand, would be much more direct. ${ }^{125}$ To protect the interests of both shareholders and employees, therefore, the shareholders also should have a right of action against union representatives on the board when the act in question was not part of a good faith effort to advance employee interests. Denying the shareholders this right of action would be a greater infringement on the policy behind the usual standard of the corporate director's fiduciary duty than is necessary to allow effective union representation, and would promote director malfeasance at the expense of both shareholders and employees. ${ }^{128}$

\section{B. Implementation of the Standards}

The best way to implement the standards offered by this Comment would be by statute. A properly drafted statute authorizing union representation would clarify the parties' legal relationships ex ante. This would encourage parties who otherwise would be fearful of legal complications to try union representation. A

generally H. HenN, HandBook of the LAw of Corporattons and Other Business ENTERPRISES 457-74 (2d ed. 1970).

125 Because all corporate profits belong to the shareholders in the final instance (at liquidation), any diminution in corporate assets has a direct impact on shareholder interests. Workers have no direct claim on corporate profits-they have bargained for a fixed wage. Of course, how much the union can bargain for depends on the corporation's financial health, but the impact of fraud, for example, would be indirect, at least in the absence of profit-sharing.

i26 Note that the proposals offered here relate to the director's fiduciary duty. Other duties of a corporate director would also apply to a union representative. Thus, for example, the union representative would be held to the usual standards with respect to negligence. These duties should normally be enforceable by either shareholders or employees if they can show the requisite injury in fact. See generally C. Wright, Handboox of the Law of Federal Courts 42-52 (3d ed. 1976) (discussing the law on standing). 
statute also might encourage experiments in union representation by giving such experiments a symbolic stamp of legitimacy. ${ }^{127}$

Any such statute, however, should be quite general. The statute should state that the usual fiduciary-duty standard for a corporate director would not apply to a union representative on the board of directors. Instead, the union official's duty would be the standard proposed by this Comment: a duty to employees first, then to the corporation as a whole when specific worker interests are not involved directly. ${ }^{128}$ Because any lawsuits against union representatives for breach of fiduciary duty will raise new issues and complex value conflicts, the courts should be given the opportunity to define the standard more specifically on a case-by-case basis. Reliance on such an approach allows amorphous standards such as "good faith" to be applied in concrete factual settings. The courts can balance the equities involved in each case. This approach will serve to prevent premature adoption of overly rigid legal standards.

In the absence of a statute, the courts should legitimize such experiments by applying the standards proposed in this Comment. The courts have developed the common law of the fiduciary duties of trustees generally ${ }^{129}$ and of corporate directors in particular..$^{130}$ Implementing and applying legal standards for union representatives would involve only a further refining of those standards, and thus would be well within the courts' competence. ${ }^{131}$

127 Cf. H. Wellangton, supra note 100 , at 46 ("The Wagner Act put government behind the unions at least to the extent that it made collective bargaining legitimate.").

128 See supra text accompanying notes 123-24.

129 See generally G. Bogert \& G. Bogert, The Law of Trusts And Trustees $\$ \$ 2-8$ ( $2 \mathrm{~d}$ ed. 1965 ).

${ }^{130}$ See H. HeNN, supra note 124, at 451 (discussing the common law basis of the fiduciary duty of corporate directors).

131 It has been suggested, however, that, when a union bargains with more than one firm in an industry, the statutory law of interlocking directorates may prevent union representation unless modified. See Steuer, Employee Representation on the Board: Industrial Democracy or Interlocking Directorate?, 16 Colum. Transnat'l. L. 255, 274-96 (1977). But see Summers, supra note 68, at 169-70. The susceptibility of the relevant statutory provisions to a judicial construction allowing union representation is uncertain and beyond the scope of this Comment, but amendment of the statute may be required. See Steuer, supra, at 274-96.

Another statutory change that would be very desirable is amendment of section 8 (d) of the National Labor Relations Act, 29 U.S.C. \$158(d) (1976), to make union representation a mandatory subject of collective bargaining. Note, supra note 90 , at 1008 .

For a general discussion of the possible antitrust ramifications of union representation, see Steuer, supra, at 270-74; Summers, supra note 68, at 179-83. The possible antitrust problems may be less serious than these authors-especially Steuer - suggest. First, if union officials on the board of "one company were to take into account the direct impact of their actions on employees in other companies, this 


\section{Application of the Standards}

Despite the obvious dangers involved in abstract speculation in the absence of a concrete factual setting, some indications of how the courts should apply the proposed standards are given below. Particular emphasis is placed on highlighting the different shareholder and employee values implicated in each situation.

\section{Access to Information}

Corporate directors commonly enjoy a broad right of inspection of corporate books and records. ${ }^{132}$ The application of this Comment's standards for a union board representative would provide the union director with the same right of access to information. ${ }^{133}$

The principal reason supporting such a rule is that the union official's representation of worker interests would be rendered ineffective if the union director did not have this access. The increased ability to scrutinize management closely, checking its excesses and inefficiencies, is perhaps the primary benefit of rep-

might actually enhance efficiency by internalizing external costs, see supra note 24 . It is, of course, possible that there would be an offsetting anticompetitive effect, but this efficiency gain should at least partly allay fears.

Second, Steuer misleads when he suggests that " $[t]$ o the extent that the workers" salaries and job security are dependent upon the profitability of the enterprise, they will have a powerful incentive to help boost their company's revenue at the expense of competition." Steuer, supra, at 272 . Although it is true that officials of a union that represented workers at only one firm in an industry would have strong incentives (although probably little ability) to help that firm gain monopoly power in the industry by increasing its market share, it is not clear that the officers of a union that bargained on an industry-wide level would generally have the same incentive. Such anticompetitive activity would, in order to have the desired effect of increasing profits, have to decrease industry output, see generally F. ScHERER, supra note 28, at 151-68, with a consequent loss of employment. Thus, any resulting wage gainswhich would be speculative, because the union could not use legal means of redress to enforce an agreement-would be counterbalanced by layoffs of union members. It is not immediately obvious that this would generally be a desirable tradeoff for union officials, especially if laid-off union members retain the right to vote in union elections. But see United Mine Workers v. Pennington, 381 U.S. 657 (1965). This same analysis would also apply to industry-wide union anticompetitive action short of outright collusion with management. Thus, although there are certainly some incentives to anticompetitive behavior, the economic incentives are not onesided. This suggests that the antitrust laws might well be adequate to deter most of whatever potential for collusion would be created by union representation.

132 See H. HeNs, supra note 124, at $\$ 216$ ("Directors as individuals enjoy, on common-law principles, a right, termed 'absolute' in some and 'qualified' in other jurisdictions, to inspect the corporate books and records, as corollary to their duties to keep informed on corporate matters."). See also the cases compiled in Annot., 15 A.L.R.2d 11 (1951).

133 For an exception, see infra text accompanying notes 144-46. In addition, the union representative's right of inspection should not extend to records not otherwise available to the union concerning the conduct and strategy of ongoing grievance proceedings. 
resentation for the employees. ${ }^{134}$ The union representative would be handicapped severely in his or her ability to monitor management without the chance to examine these records of management's performance.

If a union representative should, however, attempt to go on an extended fishing expedition through corporate records, it may be necessary for a court to delimit this privilege. In any case when it is asked to do so, the court should balance carefully the director's legitimate need for the information to carry out his role as the employees' representative against the need to avoid disruption of the corporation's ongoing business. Because of the importance of union access to such information, a court should limit this privilege only if it is used to harass management intentionally. The burden of proving at least a prima facie case of such intent should be on management. ${ }^{135}$

\section{Confidentiality of Information}

This Comment's standards yield the following rule regarding confidentiality: a union representative may release information obtained through his position on the board when such release represents a good-faith effort to advance specific employee interests; when specific employee interests are not directly involved, however, the usual director prohibitions against releasing information detrimental to the corporation and advancing a director's private interests would apply. ${ }^{136}$

134 One indication of the importance of information exchange to both union and corporation is the growing trend of establishment of joint labor-management committees, one of whose main functions is often exchange of information. See A. ArMuTY, supra note 104, at 33-41. See generally id. 7; supra note 90 and accompanying text.

This Comment has enumerated two causes of managerial inefficiency, stemming from both internal and external sources. See supra text following note 71 . The right of access addresses both sources. The information obtained by the union representative's right of access is necessary to discern the internal sources of inefficiencies. The external cause is the failure of the capital markets to perceive the internal managerial inefficiency and to correct by the threat or actuality of takeovers. See supra notes 84-89 and accompanying text. The use and publicizing of the obtained information-the confidentiality of such information is dealt with infra notes 136-42 and accompanying text-is necessary to inform the capital markets to ensure their more competent regulation of internal managerial inefficiency.

135 Management could establish a prima facie case of intent to harass by showing that the effect is to hamper severely the conduct of business. The union then would have the burden of showing some legitimate purpose in seeking the information.

136 See supra text accompanying notes 9-11. See generally 3 W. FLETCHER, supra note 31 , at $\$ \$ 884-906$. For a further limitation related to the union representative's ability to release confidential corporate information, see infra text following note 141 and text accompanying note 142 . 
This rule provides a reasonable standard for three reasons. First, this rule is merely the logical and necessary corollary of the prior rule giving union directors access to such information; it likewise is required to effectuate the union director's representation of employee interests. ${ }^{137}$ The increased oversight of management by direct observation and by access to pertinent data is unhelpful if the uncovered management inefficiencies cannot be revealed publicly or used for bargaining leverage. ${ }^{\mathbf{1 3 8}}$ Moreover, there are few other benefits of such board membership when the union representation is only a small percentage of total board votes. ${ }^{139}$

The second reason this rule is reasonable is that applying a more stringent restriction would be impracticable. Prohibiting disclosure of information by the union representative would require him or her to mislead other union officials intentionally whenever confidential information led the representative to support union positions or actions different from those that appeared best to other union officials. The result of such deception would be either loss of faith by workers and other union leaders in the representative's abilities or acquiescence by the others based on the assumption that he knew more than they did. Either result would be undesirable, the former because it would create strains among the union leadership, and the latter because it would provide the board representative with an unnecessary increase in power relative to other union officials, with a consequent diminishing of internal union democracy.

The third justification for the confidentiality rule proposed by this Comment is that to require otherwise would raise very serious questions concerning the union representative's duty under Landrum-Griffin section 501.140 Such withholding of information would seem to contravene explicitly the command of section 501 to "refrain from dealing with the [union] as an adverse party." 141

The union representative's freedom under this rule would not be unbounded, however. Disclosure of otherwise confidential information would have to be part of a good-faith effort to advance employee interests. In order to preserve the interests of the stockholders to the greatest extent possible, moreover, there should be

137 See supra note 134.

138 See supra note 134.

139 U.A.W. president Fraser is one of eighteen Chrysler board members. See New York Times, Nov. 26, 1979, at D9, col. 4 .

140 See Labor-Management Reporting and Disclosure [Landrum-Griffin] Act $\S 501,29$ U.S.C. $\$ 501$ (1976).

141 Id. 
a strong presumption that legitimate trade secrets, such as product specifications, marketing strategies, and patented information, do not fall into the category of information that the union representatives may release. This presumption is needed because the stockholders' interests are particularly implicated in the confidentiality of this kind of information. Furthermore, any relationship between release of this kind of information and employee welfare usually will be very indirect and speculative. ${ }^{142}$

\section{Collective Bargaining Strategy}

Board discussion of collective bargaining strategy is one area in which board representation of worker interests makes no sense. To provide a union representative with a legal right to participate in discussions of this type would conflict with the adversarial model of collective bargaining that has been adopted in the United States, ${ }^{143}$ and would provide the union with an unfair advantage in that process. Hence, the union representative should be required to absent himself from such board discussions (unless invited to participate). ${ }^{144}$ For similar reasons the union representative's right of access to corporate information should be limited not only by the normal standard for a corporate director, ${ }^{145}$ but also with respect to information about strategy for ongoing and forthcoming collective bargaining. ${ }^{146}$

142 One example of an allowable disclosure would be to a legal counselor. Such a counselor should then be held to a duty of confidentiality. "Judging from the experience in Germany and Scandinavia, serious breaches of confidentiality would be unlikely to occur." Note, supra note 90, at 992. For a very thoughtful discussion of the confidentiality issue, see Summers, supra note 68, at 170-73. Summers suggests that the corporation's need for secrecy has been exaggerated. Id.

143 See generally Murphy, supra note 2, at 760-61.

144 Douglas Fraser, U.A.W. president and Chrysler director, indicated shortly before his election to the Chrysler board that "he would stay out of all board actions dealing directly with collective bargaining strategy but would take full part in discussion and votes on everything else, including basic policies on collective bargaining. . . " Raskin, The Labor Leader as Company Director, New York Times, Apr. 27, 1980, at F15, col. 1. This is a reasonable distinction as long as board discussion of these "general policies" would not result in disclosure to the union representative of information concerning short-term collective bargaining strategy.

One advantage of making discussion of the subject of union representation part of the collective bargaining process is that disputes over issues such as what meetings the union representative would be barred from can be resolved privately through mechanisms set up by the collective agreement. For example, the parties could indicate that all such disputes were to be resolved by binding arbitration. Where no such express provisions are found, but the wording of the collective agreement's arbitration clause is broad, the courts should require the parties to submit such disputes to the arbitrator.

145 See supra note 132 and accompanying text.

146 This rule should be construed narrowly to prevent abuse by the rest of the board of directors. For example, although plant closings arguably affect collective 


\section{Industry-Wide Bargaining}

In certain situations the union bargains on an industry-wide basis. In those industries the union board representative should be allowed to take into account the welfare of all workers in the industry, rather than a particular corporation's employees alone. The interest of the union is industry-wide, and to require a union representative to consider only the interests of workers in one firm would injure the union's interests by lessening its ability to coordinate its policies on an industry-wide basis.

\section{Contrary Agreements}

The precise standards adopted by the courts for the powers of a union board representative for the most part should be flexible enough to apply only when the parties have made no express agreement to the contrary. Parties considering experimenting with union representation in general should be free to structure it to meet the specific needs of the union and corporation involved. This freedom would encourage such experiments.

This flexibility should not, of course, extend to the union representative's fiduciary duty to the union members or allow the parties to override any important public policies. Certainly, the union official's duty to represent worker interests should not be considered waivable by agreement between the union and the corporation. The beneficiary of the duty-the worker-would have no input into such a decision, which would frustrate the requirements of adequate employee representation embodied in the section 501 statutory provisions. ${ }^{147}$

\section{CoNCLUSION}

Because of the problem of conflicting fiduciary duties to shareholders and employees, union representation on corporate boards is problematical under current legal standards. A union official serving on a corporate board would in many cases be forced to choose between breaching his duty to employees in the union's bargaining unit and breaching the usual corporate director's duty

bargaining strategy, normally they are not even subject to mandatory bargaining. See First Nat'l Maintenance Corp. v. NLRB, 452 U.S. 666 (1981). In any event, the exception is for discussions of collective bargaining strategy, not of issues that might affect or arise in collective bargaining.

147 Cf. Serving Two Masters, supra note 14, at 648 ("Courts . . . have found violations of section 501 only in two extreme situations. First, they have intervened when union officials manipulated democratic procedures within a union. In these circumstances, employees may be unable to ensure that their interests are protected."). 
to the shareholders. This Comment has therefore examined the desirability of modifying the current legal standards to allow representation of worker interests on the corporate board.

Although the economic effects of union representation are somewhat speculative, there is reason to believe that significant gains in efficiency would result. Voluntary union representation would be likely to reduce transaction costs in the governance of the collective bargaining agreement and would reduce the ability of management to run the corporation so as to further their own interests rather than those of the shareholders. This likelihood of increased efficiency provides important support for this Comment's conclusion that the usual director's fiduciary duty should be modified to permit union representation on the employees' behalf.

Examination of the policies underlying collective bargaining provides additional support for union representation. Union representation is seen best as an extension of the collective bargaining process, and as a complementary mechanism for furthering the labor law objectives of promoting industrial democracy and reducing industrial strife. Moreover, union representation experiments would permit an exploration of the contours and ramifications of an emerging conception of the corporation as a community of interests.

This Comment's proposed standards for union representatives for the most part merely redirect the corporate director's fiduciary duty from shareholder to employee. In applying the standards, though, the implications of different possible rules for the different interests involved must be weighed in order to avoid injustice to shareholder, employee, or union. 